UDC 331.215.24

O. Velychko,

Doctor of Economic Sciences, Professor, Head of the Department of Management and Law, Dnipro State Agrarian and Economic University, Ukraine

ORCID ID: 0000-0003-2700-0329

L. Velychko,

PhD in Public Administration, Senior Lecturer of the Department of Economics, Entrepreneurship and Management of Enterprises, Oles Honchar Dnipro National University, Ukraine

ORCID ID: 0000-0002-8255-8774

Ye. Yabnin, Master's degree of Management, Dnipro State Agrarian and Economic University, Ukraine

ORCID ID: 0000-0001-8754-2846

DOI: $10.32702 / 2306-6806.2021 .3 .40$

\title{
LOGISTICAL MODELS OF COMPETITIVE DEVELOPMENT IN CONDITIONS OF THE DIGITAL TRANSFORMATION IN PRODUCTION AND MARKETING BUSINESS PROCESSES
}

\author{
О. П. Величко, \\ А. е. н., професор, завідувач кафедри менеджменту і права, \\ Аніпровський державний аграрно-економічний університет, Україна \\ А. А. Величко, \\ к. держ. упр., Аоцент кафедри економіки, підприємництва та управління підприємствами \\ Дніпровський національний університет імені Олеся Гончара, Україна \\ С. С. Ягнін, \\ магістр менеджменту, Аніпровський державний аграрно-економічний університет, Україна
}

\section{ЛОГІСТИЧНІ МОАЕАІ КОНКУРЕНТНОГО РОЗВИТКУ В УМОВАХ ЦИФРОВОЇ ТРАНСФОРМАЦІЇ ВИРОБНИЧИХ ТА МАРКЕТИНГОВИХ БІЗНЕС-ПРОЦЕСІВ}

Contemporary operational management is focused on rational organization of business processes in combination with a high level of efficiency for satisfying demands of customers. Manufacturing and marketing represent one of the main operational processes which at the same time act as essential centers of costs and profits at an enterprise. Efficient modeling of development in such business processes can be achieved by modern methods of rationalistic logistics. However one of the actual issues remains unsolved - the optimal combination of such methods with the focus on current purposes of business, strategy, market situation, development of the field and so on. Considering the above, the article grounds the formation of the alternative complex of rationalistic logistics methods which can provide efficient planning of the competitive development in manufacturing and marketing operational processes in the system of managing an enterprise. The materials for the research included data of the operational activity of business entities, which work on the Ukrainian market of building materials. The process of the research included the application of such special methods as graphic design, logistical modeling, SPACE-analysis, matrix methods and so on. Each of the stages was focused on solving local tasks, which in the complex made possible to showcase the efficacy of applying the integrated packet of logistical models. In particular the research represented firstly, the application of the method of econometric modeling as one of the ways of rationalistic logistics; secondly, usage of the logistical model of profiling for comparing the achieved level of an enterprise with current market demands for organizing business-processes; thirdly, to carry out logistical modeling of the competitive development of the organization based on SPACE-analysis; fourthly, to draw up the logistical model of strategic development in manufacturing and marketing business processes based on the matrix BCG. According to the results of the research, the integrated complex of logistical models of competitive development in manufacturing and marketing business processes in operational management at enterprises have been suggested. The practical value of the research can be found in the development of various possibilities for the business in implementing the integrated packet of logistical modeling. The results of the research can be used in strategic planning of the operational activity at modern enterprises. 
Сучасний операційний менеджмент орієнтований на раціональну організацію бізнес-процесів у поєАнанні з високим рівнем ефективності задоволення вимог Споживачів. Виробництво та маркетинг є одними із основних операційних процесів, які одночасно виконують роль важливих центрів витрат та доходів на підприемстві. Ефективне моделювання розвитку цих бізнес-процесів може бути забезпечено за допомогою сучасних засобів раціоналістичної Аогістики. Однак однією із актуальних проблем залишається оптимальна комбінація таких засобів з орієнтацією на поточні цілі бізнесу, стратегію, ринкову ситуацію, розвиток галузі та ін. Зважаючи на це, у статті обгрунтовано формування альтернативного комплексу засобів раціоналістичної логістики, який може забезпечити ефективне планування конкурентного розвитку виробничих та маркетингових операційних процесів у системі управління підприємством. Матеріалами Аля дослідження стали дані операційної діяльності суб'єктів підприємництва, які працюють на українському ринку будівельних матеріалів. Процес наукового пошуку передбачав застосування таких спеціальних методів, як графічний,дизайн, Аогістичне моделювання, SРАСЕ-аналіз, матричні методи та ін. Кожен із етапів був зорієнтований на вирішення Аокальних завдань, що у комплексі дозволяло продемонструвати ефективність застосування інтегрованого пакету Аогістичних моделей. Зокрема, доСлідження передбачало, по-перше, застосування методу економетричного моделювання як одного із засобів раціоналістичної Аогістики; по-друге, задіяння Аогістичної моделі профілювання для зіставлення досягнутого рівня підприємства та поточних вимог ринкущодо організації бізнес-процесів; по-трете, Проведення Аогістичного моделювання конкурентного розвитку організації на основі SPACЕ-аналізу; Почетверте, формування логістичної моделі стратегічного розвитку виробничих та маркетингових бізнеспроцесів на основі матриці ВС G. За результатами досліджень запропоновано інтегрований комплекс логістичних моделей конкурентного розвитку виробничих та маркетингових бізнес-процесів в управлінні операційною діяльністю підприемств. Практична цінність досліАЖення полягає У розвиткУ варіативних можАивостей, АЯ бізнесущодо застосування інтегрованого Пакету оогістичного моделювання. Результати можуть бути використані в стратегічному плануванні операційної,діядьності сучасних підприемств.

Key words: operation, solution, marketing, manufacturing, logistics, complex, process, modeling, integration, strategy

Ключові слова: операчіи, рішення, маркетинг, виробничтво, логістика, колплекс, прочес, моделювання, інтеграчія, стратегія.

\section{SETTING A TASK}

Nowadays in the contemporary conditions of business activity by different types of organizations there is an essential task of improving the level of economic stability. The improvement of positions for the sustainable economic development of enterprises depends on the proximity to strategic and tactical aims. In times of crises which frequently accompany the process of economic activity, the key tactical aims are the termination of insolvent companies, restoration of economic sustainability, changes in the management strategy with the purpose of promoting social and economic growth, and so on.

Modern statistics demonstrates inefficient application of manufacturing-commercial potential by many enterprises in Ukraine. It represents a low efficiency of business in many fields of economy. Therefore the growth in manufacturing efficiency is one of the most essential tasks for the government as well as of enterprises. The base for the success of any organization is constant enhancement of the business efficiency, systematic analysis of manufacturing-business activity, in particular implementation of means which are aimed at promoting social-economic efficiency of management in the entrepreneurial activity.

At that business processes represent an essential object of management in the system of modern operational management. And under the conditions of high paces of innovations and competitive development such spheres as manufacturing and marketing require special attention. Efficient strategic planning of their competitive development can be provided by implementing different methods. However special attention should be paid to the ways of rationalistic logistics [13]. These ways, unlike provision logistics, are directly focused on modeling efficient managerial decisions based on rational or quantitative approaches. But for each separate situation or a field of business it is important to determine the optimal complex of ways which might provide high-quality modeling of the strategic development of an enterprise in competitive conditions. Therefore the search for such combination of instruments of logistical modeling is an essential and actual task for the scientific research.

\section{ANALYSIS OF THE LATEST PUBLICATIONS}

The system of the operational management has been the object of a large number of researches carried out by many scientists. Typically it is considered as the priority component of the competitive development of an enterprise in the long-term strategic measurement. At that the issue of interconnection between the process of the operational management and stable development in business systems appears [7].

The processes of manufacturing and marketing are also widely spread objects of strategic planning of the competitive development. In particular it is demonstrated in publications by A. Shokuhi and S.A. Nabavi Chashmi [11], M.M. Aliu and E.O. Oni [2], M. Rakic et. al. [9]. Particularly A. Shokuhi and S.A. Nabavi Chashmi consider the initial role in provision of the competitive development in the differentiation strategy based on the not precise method TOPSIS [11]. At the same time M.M. Aliu and E.O. Oni emphasize the importance of any marketing strategy in achieving competitiveness of business [2]. Similar estimation takes place in competitive advantages of manufacturing strategies [6].

Wherein P.R. Kleindorfer et. al. propose the integrated approach to development of strategic decisions in manufacturing and marketing business strategies [7]. And this approach regularly promotes efficient solution to complex managerial situations.

Modeling method is of great importance in this case [14]. For instance, D. Breuker et. al. claim that predicting models in the system of management provide the way of resolving 
business processes [3]. Within this context J. Brunk et. al. add that predicting modeling of unfavorable events makes possible to keep the consistency of processes with the aims of the company [4]. However N. Mehdiyev et. al. determine modeling monitoring of business processes as an important competitive advantage of a company in the system of its strategic planning [8].

According to Ye.V. Krykavs'kyj et. al., logistical models and methods are some of the most essential components in the complicated integrated approach to efficient planning of business processes in the creation of the value chain [1]. For example W.E. Soto-Silva et. al. researched such models for managing operations in the agricultural supply chain. Furthermore the authors illustrate the prospect of applying such tools of the grounded decisions in the operational management [12].

Moreover S. Chang et. al. pay close attention to the possibility of optimizing the selection of strategic initiatives [5]. And ways or rationalistic logistics can be widely used for providing such optimization [13]. Besides such methods were used by T.R.P. Ramos et. al. when evaluating the alternative approaches of the operational management to organization of waste collection. However several logistical methods have been used simultaneously for this purpose [10].

In spite of a wide range of the research, carried out in the field, such a pproaches require additional development and improvement. In particular it concerns formation and implementation of the integrated packets of logistical models adapted to the market situation, development of the field, and so on.

\section{METHODOLOGY}

The purpose of the research is to form a set of measures of rationalistic logistics, which can provide efficient planning of the competitive development in manufacturing and marketing operational processes in the system of managing an enterprise.

The object of the research is the process of logistical modeling a competitive development of manufacturing and marketing business processes in the management of the operational activity of enterprises.

Materials of the research were the data of the operational activity between 2015 and 2019 of business entities which work at the Ukrainian market of building materials. In particular LLC 'Albatross', PE 'Syaivo-Invest', PE 'Kapro', LLC 'Mikshor', LLLC 'Light-Lux', PJSC 'KZS', and LLC 'Prombudpostach'.

In the process of the scientific research special methods were used such as econometric modeling, SPACE-analysis, graph design, matrix modeling, and so on.

The research was carried out in four stages, each stage designed to solve certain tasks. In particular:

- first stage - implementation of the economical modeling method as one of the ways of rational logistics in modern conditions;

- second stage - application of the logistical model of profiling for comparing the achieved level of an enterprise with requirements of the market in organization of business processes;

- third stage - carrying out logistical modeling of the competitive development of organizations based on SPACEanalysis;

- fourth stage - formation of the logistical model of strategic development in manufacturing and marketing business processes based on Boston Consulting Group Matrix.

\section{RESULTS OF THE RESEARCH}

At the first stage such method of the rationalistic logistics as econometric modeling has been used. With the help of this method the affects of costs on improving business processes and expenses on staff developing on the formation of the profit generated by LLC 'Albatross' have been
Table 1. Data of observation for determining the affect of costs spent on improving business processes and staff development on generation of financial results

\begin{tabular}{|c|c|c|c|c|c|c|}
\hline \multirow{2}{*}{ Variables } & \multicolumn{6}{|c|}{$I$} \\
\cline { 2 - 7 } & 2014 & 2015 & 2016 & 2017 & 2018 & 2019 \\
\hline$d_{i}$ & 125 & -239 & 542 & 668 & 923 & 996 \\
\hline$p_{i}$ & 5 & 5 & 10 & 14 & 22 & 39 \\
\hline$k_{i}$ & 4 & 3 & 5 & 8 & 12 & 17 \\
\hline
\end{tabular}

studied. As a result the regression equation was determined, which defines quantitative correlation between the costs and profits. Estimation of forming the profit of an enterprise with the help of the econometric modeling requires a set of factors. They can affect the amount of profit; create the array of statistic information, create correlation-regression dependencies, build regression models, evaluation of general adequacy of models and their financial-economic interpretation.

Essential costs which affect the amount of financial results $\mathrm{d}$, are the costs spent on improving business processes $\mathrm{p}$ and staff development $\mathrm{k}$. Data on economic results and costs spent on improving business processes and staff development of enterprises in 2014-2019 have been represented in table 1.

In particular, based on the provided data the linear progressive model was built, which determines the dependency of the profit of enterprised $d_{i}$ on the sum of costs spent on improving business processes $p_{i},(i=\overline{1, n}, \mathrm{n}-$ number of years which are considered).

$d_{i}=a_{0}+a_{1} p_{i}+l_{i}$ point);

where $a_{0}-$ constant component of profit $d_{i}$ (reference

$a_{1}$ - regression coefficient;

$l_{i}-$ deviation of actual values of profit $d_{i}$ from the estimate (expected value) $y_{i}$ of the mean value of costs spent on improving business processes and staff development.

The comparative analysis of econometric models showed that if the costs spent on improving business processes increased by one thousand UAH, if all other conditions remain unchanged, the profit of the enterprise would increase only by 0.27 thousand UAH. At the same time if costs on staff development increase by one thousand UAH, the profit of the enterprise will increase by 0.76 thousand UAH. Thus it is possible to conclude that the costs spent on improving business processes affect significantly lower the amount of the profit generated by the enterprise rather than the costs spent on staff development. However the costs spent on improving business processes impact the amount of the generated profit more systematically. It is essential to take into account while modeling the competitive development of the enterprise.

At the second stage of the research, the model of profiling has been used to compare the requirements of the market to the level of organizing business processes with the achieved level of the enterprise. In the modern conditions after the clear description of the corporative and marketing strategies, the process of creating corresponding capacities should begin. In practice it happens not frequently. The enterprise already exists and its capacities to a bigger extent meet the set requirements. The formation of completely new capacities is rather unlikely. However at that it is essential to determine the direction of the competitive development correctly. To boost this process the method of profiling is typically used. The most essential characteristics of the activity of the enterprise and the market have been formed using the matrix (table 2).

The analysis proved that while carrying out the order of sandwich-panels is faster than the mean value required 
Table 2. Model of profiling for sandwich-panels by LLC 'Albatross' at the market of Ukraine (based on the market research)

\begin{tabular}{|c|c|c|c|c|c|c|c|c|c|c|c|}
\hline \multirow{2}{*}{ Indicator } & \multicolumn{11}{|c|}{ Range } \\
\hline & 0 & 1 & 2 & 3 & 4 & 5 & 6 & 7 & 8 & 9 & 10 \\
\hline $\begin{array}{c}\text { Flexibility of } \\
\text { projecting }\end{array}$ & Standard & & & * & \# & & & & & & If ordered \\
\hline Quality of supply & $\begin{array}{c}\text { Possible } \\
\text { deviations }\end{array}$ & & \# & & & & & & * & & $\begin{array}{l}\text { Non-deficit } \\
\text { supply }\end{array}$ \\
\hline $\begin{array}{c}\text { Flexibility of the } \\
\text { amount }\end{array}$ & Stable & & \# & $*$ & & & & & & & Variable \\
\hline $\begin{array}{c}\text { Time of carrying out } \\
\text { the order }\end{array}$ & Long-term & & & & \# & & & * & & & From the stock \\
\hline $\begin{array}{c}\text { Price } \\
\text { competitiveness }\end{array}$ & Low & & & & & * & \# & & & & High \\
\hline Reliability & Tolerant & & & $*$ & & & & \# & & & Critical \\
\hline$*$ achieved 1 & oy the ent & & & & & $\begin{array}{r}\text { ave } \\
\mathrm{t}\end{array}$ & & & & & $\begin{array}{l}\text { f the market to } \\
\text { processes }\end{array}$ \\
\hline
\end{tabular}

by the market. Therefore it can be used as an advantage over competitors. Besides it is possible to save resources and meet market requirements by this criterion. The similar situation concerns the quality of supplying the goods manufactured by LLC 'Albatross'. Again there are two options: 1) decrease the level of organizing business processes to the requirements of the market; 2) leave the level of organizing business processes at the same level as an advantage over competitors. The latter will be more reasonable. Moreover the enterprise does not have a sufficient level in the reliability of own sandwich-panels which is required by the average consumer at the market. Overall by the sum of technical characteristics the company provides a relatively low quality of goods that it is required at the market. Undoubtedly it is necessary to modernize the technology and improve the level of competitiveness. Furthermore the goods manufactured by LLC 'Albatross' are cheaper than they are ready to be bought by customers at the Ukrainian market. It is also a corresponding advantage over competitors. However in prospect, after improving technological parameters of the goods, it is reasonable to focus on increasing the price at the Ukrainian market.

In this case the operational management can provide such a useful thing as the creation of logical and consequent

Table 3. Estimation of efficiency indicators in business processes at enterprises at the market of building materials, 2019

\begin{tabular}{|c|c|c|c|c|c|c|}
\hline \multirow[b]{2}{*}{ \# } & \multirow[b]{2}{*}{ Indicator } & \multicolumn{5}{|c|}{ Estimation } \\
\hline & & $\begin{array}{l}\text { LLC } \\
\text { 'Albat } \\
\text { ross' }\end{array}$ & $\begin{array}{l}\text { PE 'Syaivo- } \\
\text { Invest' }\end{array}$ & $\begin{array}{c}\text { PE } \\
\text { 'Kapro' }\end{array}$ & $\begin{array}{c}\text { LLC } \\
\text { 'Mikshor' }\end{array}$ & $\begin{array}{l}\text { LLC } \\
\text { 'Light- } \\
\text { Lux' }\end{array}$ \\
\hline \multicolumn{2}{|c|}{ Competitive strength } & 54 & 51 & 61 & 42 & 57 \\
\hline 1 & $\begin{array}{l}\text { Index of } \\
\text { autonomy }\end{array}$ & 1 & 5 & 7 & 7 & 10 \\
\hline 2 & $\begin{array}{l}\text { Productivity of } \\
\text { labor }\end{array}$ & 10 & 3 & 5 & 4 & 2 \\
\hline 3 & $\begin{array}{l}\text { Index of labor } \\
\text { loyalty }\end{array}$ & 8 & 10 & 10 & 8 & 4 \\
\hline 4 & $\begin{array}{l}\text { Index of ratio of } \\
\text { commodity units }\end{array}$ & 8 & 8 & 10 & 10 & 10 \\
\hline 5 & Stock turnover & 4 & 10 & 6 & 4 & 5 \\
\hline 6 & $\begin{array}{l}\text { Index of revenue } \\
\text { growth }\end{array}$ & 9 & 7 & 9 & 7 & 10 \\
\hline 7 & $\begin{array}{l}\text { Profitability of } \\
\text { product sales }\end{array}$ & 10 & 3 & 6 & 4 & 6 \\
\hline 8 & $\begin{array}{l}\text { Profitability of } \\
\text { own capital }\end{array}$ & 4 & 5 & 8 & -2 & 10 \\
\hline
\end{tabular}

strategy. Firstly it makes possible to identify its distinctive competence (whether the organization is better by volumes, quality, reaction to changes in demands of customers and so on). If it is possible to determine the distinctive area of competence, it will be necessary to develop and popularize it. Operational strategic management has to be focused on strong directions, and the enterprise as a whole has to encourage and improve their development (if there is sufficient sales market). Secondly, operational management can compare the company's strategy with the demands of the market where the company operates. Hence, all inconsistencies will be revealed in processes, workforce, equipment, location and systems of control. Then it is necessary to prioritize and rationally correct them if possible.

At the third stage of the research logistical modeling of the competitive development of the company based on SPACE-analysis was carried out. To estimate the level of competitiveness, the input information on different facets of business activity was used from enterprises which specialize in manufacturing building materials. Therefore initial analysis of strengths and weaknesses was carried out (table 3). Thus in 2019 for LLC 'Albatross' the competitive strength was estimated only at 54 points which is 7 points lower than the leader PE (private enterprise) 'Kapro'. Moreover it is 3 points less than LLC 'Light-Lux' (second position at the market). However, in 2018 the competitive strength of LLC 'Albatross' was 66 and 68 points respectively. Consequently this company took the highest position among all enterprises-competitors so it was the leader at that time. But it is essential to note that for all the studied companies it is preferable to implement methods of overcoming weaknesses.

Then the application of the SPACE-analysis model was used to evaluate the market position, and strategy of the enterprise at the market of building materials. The main stage of SPACE-analysis is to build the vector of strategy of competitiveness in the coordinate system SPACE (figure $1)$. The weighted estimate of the financial power (FP) is 4.0 points; competitiveness $(\mathrm{CP})-8.0$ points; attractiveness of the field (AF) - 6.5 points; stability of the field (SF) - 3.8 points. The vector starts in point $A$. The end of the vector is concentrated in point $\mathrm{B}$. General coordinates: $y=F P-S F ; x=A F-C P$. Respectively for the enterprises which are the objects of the estimate the coordinates equal: $\mathrm{x}$ $=6.5-8.0=-1.5 ; \mathrm{y}=4.0-3.8=0.2$.

A conservative strategy is an essential direction in the competitiveness of LLC 'Albatross' in the SPACE coordinate system. Thus the enterprise must keep its positions at the market and manufacture diversified goods. Such a strategy will satisfy the demands of customers; the existing advertising and marketing features of the company should be implemented It is vital to find innovation partners to expand the sales markets.

Overall, based on the algorithm of the graphanalytical estimation method 'Square potential', qualitative and quantitative interconnections between separate components of the potential of the studied enterprise have been determined. It was made with the purpose of timely grounding and implementing managerial decisions on increasing efficiency of LLC 'Albatross' as well 


\section{ЕКОНОМIЧНА НАУКА}

as its level of development and competitiveness (figure 2).

Vectors of the enterprise are differently developed. In particular the most problematic is vector 'Marketing'. It decreases the level of competitiveness of the potential at LLC 'Albatross'. Therefore to increase the competitiveness it is necessary to urgently balance elements of the potential: manufacturing, logistics marketing, and finances. The company does not pay sufficient attention to the formation of the professional system of promoting goods at the market. Thus it is reasonable to reconsider the organization of the management process at the enterprise in order to balance the components of the enterprise's potential. To create the competitive advantages of LLC 'Albatross' it is worth considering the affect

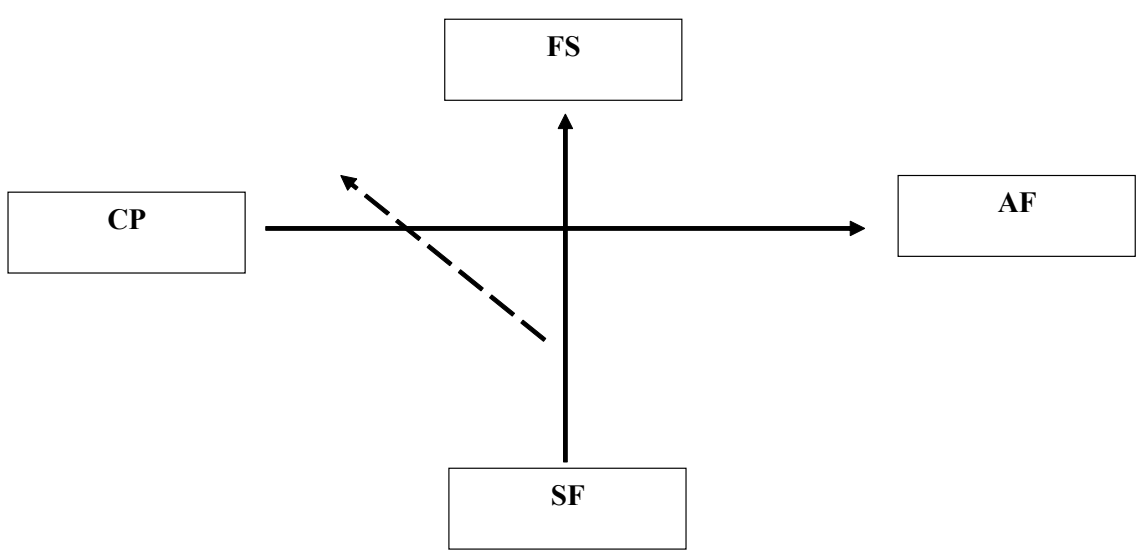
of the competitive environment, survey the market and demands of customers.

At the fourth stage of the research modeling of the strategic development of manufacturing and marketing processes was carried out on the basis of the Boston Consulting Group Matrix. According to the methodology of building the BCG Matrix, the mean share of LLC 'Albatross' at the market and its competitors have been determined (figure 3).

The results of building the model testify that Sector 'A' includes manufacturing and sale of building metal profiles. Those are the leaders of the product portfolio manufactured by LLC 'Albatross'. Fast market growth is typical for that kind of goods. The most efficient strategy towards those kinds of goods can be investing profits in production increase (widen the areas, allocation of profits into additional machinery, labor force, and so on). Sector ' $\mathrm{B}$ ' includes manufacturing and sale of corrugated board. These goods take a relatively high share at the market though their potential for further grow th has almost run out. Therefore it is obvious that this sector gets more financial resources than it needs. The most efficient marketing strategy for this kind of goods is the strategy of keeping market advantages with partly reduction in manufacturing capacities. As for the manufacturing and sale of sand wich-panels (sector ' $\mathrm{C}^{\prime}$ ), it is characterized by a fast market growth and insufficient market share. At the initial stage these goods will provide either small profits or cause losses for LLC 'Albatross'. However there is potential development of the market share in prospect. For this type of goods the efficient strategy is to expand the market share at the expense of the intensive management. Moreover it is reasonable to redistribute general technical, staff and financial resources for developing goods from sector ' $C$ '. As for sector ' $D$ ', it includes manufacturing and sale of roofing materials. This type of goods is characterized by a relatively low market share and a slow growth rate. Hence the market of these goods does not develop and there is almost no prospect for developing it. The demand for these goods decreases and there are strong competitors which specialize in manufacturing similar goods. In particular the competitors are PJSC 'KZS' and LLC 'Prombudpostach', which respectively offer high-quality and cheap technology. Therefore it might be reasonable to gradually withdraw this type of business activity and

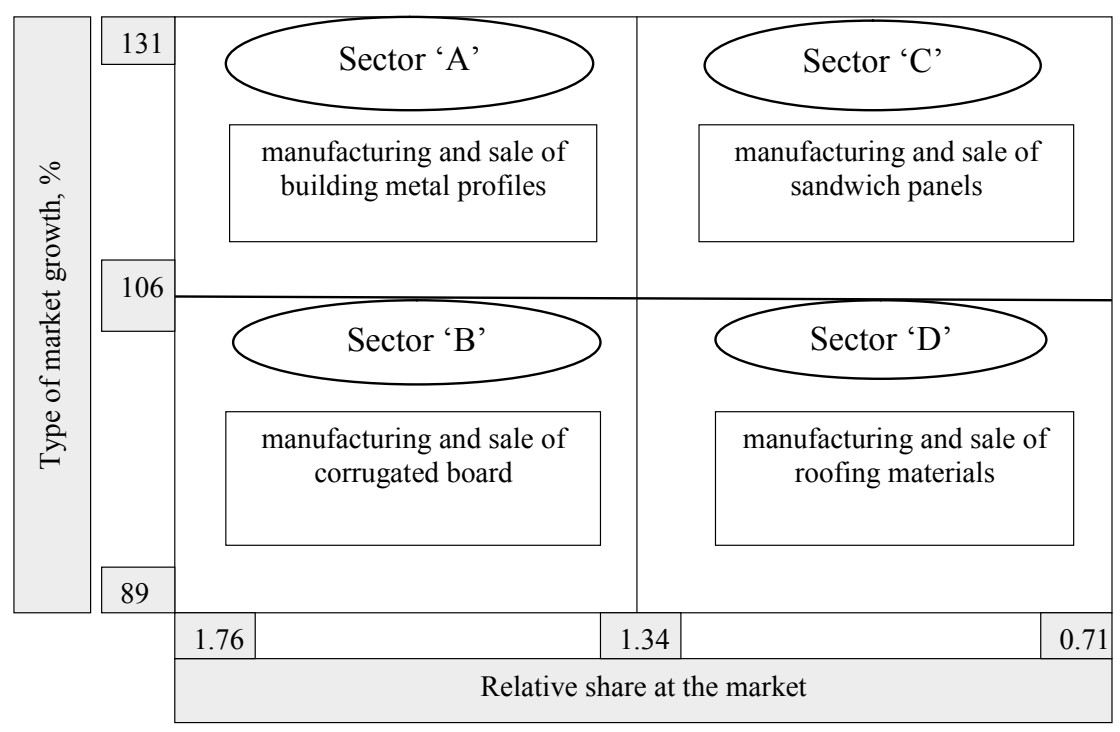

Figure 2. Square of the competitive potential of the company at the market of building materials

igure 1. Determination of the vector of the competitiveness strategy at the market of building materials in the SPACE coordinate system

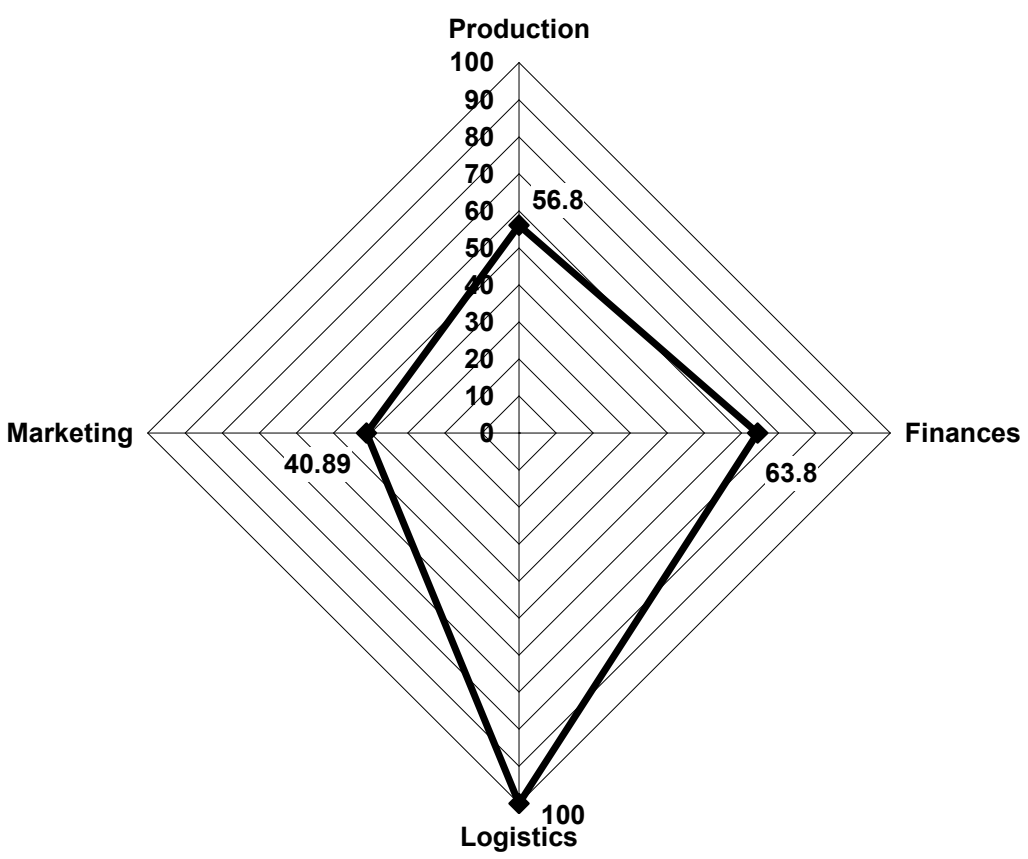

Figure 3. Model of strategic analysis of manufacturing and marketing business processes, which are the sources of income for LLC 'Albatross' 
release resources for manufacturing other types of goods for LLC 'Albatross' (in particular manufacturing and sale of sandwich-panels).

\section{CONCLUSIONS}

Efficient planning of the competitive development of manufacturing and marketing business processes in the system of operational management can be provided by means of combined implementation of several rationalistic logistics approaches. For enterprises which operate at the market of building materials, the complex approach can be recommended: method of econometric modeling, profiling logistical model; method of SPACE-analysis and logistical model of the strategic development of a company based on the BCG Matrix. Simultaneous application of these approaches made possible to determine that for the stable economic development of an enterprise it is necessary to provide optimization of costs spent on improving manufacturing and marketing business processes, which create a relatively high labor motivation. Moreover it is essential to systematically allocate finances for staff development with the purpose of increasing their influence on improving financial results. Furthermore technical-innovation refit of certain business processes can increase manufacturing capacities of goods with appropriate quality and widen the product range. It will promote competitiveness of the business. And the suggested operational strategies in prospect may significantly improve the existing competitive status. Further research is worth focusing on optimizing the processes of provisional logistics in the sphere of manufacturing-sale activity.

$\Lambda$ ітература:

1. Крикавський Є., Похильченко О., Фертч М. Аогістика та управління ланцюгом поставок. ьвів: Видав-

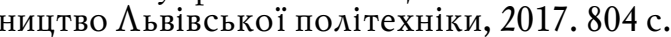

2. Aliu M.M., and Oni E.O. (2020), "A review on marketing strategies and sustainable competitive advantage of smes in the manufacturing sector", Covenant Journal of Entrepreneurship, vol. 4, no. 2, pp. 111-117.

3. Breuker D., Matzner M., Delfmann P., and Becker J. (2016), "Comprehensible Predictive Models for Business Processes", MIS Quarterly, vol. 40, no. 4, pp. 1009-1034.

4. Brunk J., Stierle M., Papke L., Revoredo K., Matzner M., and Becker, J. (2021), "Cause vs. effect in contextsensitive prediction of business process instances", Information Systems, vol. 95, p. 101635.

5. Chang S., Zhang Z., Wang X. and Dong Y. (2020), "Optimal acquisition and retention strategies in a duopoly model of competition", European Journal of Operational Research, vol. 282, no. 2, pp. 677-695.

6. Hosseini A.S., Soltani S. and Mehdizadeh M. (2018), "Competitive advantage and its impact on new product development strategy (Case study: Toos Nirro technical firm)", Journal of Open Innovation: Technology, Market, and Complexity, vol. 4, no. 2, pp. 17-22.

7. Kleindorfer P.R., Singhal K., and Van Wassenhove L.N. (2009), "Sustainable operations management", Production and operations management, vol. 14, no. 4, pp. 482-492.

8. Mehdiyev N., Evermann J. and Fettke P. (2020), "A novel business process prediction model using a deep learning method", Business \& information systems engineering, vol. 62 , no. 2, pp. 143-157.

9. Rakic M., Rakic B. and Stanojevic L. (2018), "Consumer Ethnocentrism-Marketing Challenge for Companies: The Case of Serbia", Management: Journal of Sustainable Business and Management Solutions in Emerging Economies, vol. 23, no. 3, pp. 81-92.

10. Ramos T.R.P., de Morais C.S., and Barbosa-Povoa A.P. (2018), "The smart waste collection routing problem: Alternative operational management approaches", Expert Systems with Applications, vol. 103, pp. 146-158.

11. Shokuhi A. and Nabavi Chashmi S.A. (2019), "Formulation of Bank Melli Iran Marketing Strategy Based on Porter 'S Competitive Strategy", Journal of Business-toBusiness Marketing, vol. 26, no. 2, pp. 209-215.

12. Soto-Silva W.E., Nadal-Roig E., Gonzalez-Araya M.C., and Pla-Aragones L.M.(2016), "Operational research models applied to the fresh fruit supply chain", European Journal of Operational Research, vol. 251, no. 2, pp. 345-355.

13. Velychko O. and Velychko L. (2017), "Logistical modelling of managerial decisions in social and marketing business systems", Journal of International Studies, vol. 10, no. 3 , pp. $206-219$.

14. Velychko O., Velychko L., Butko M. and Khalatur S. (2019), "Modelling of strategic managerial decisions in the system of marketing logistics of enterprise", Innovative Marketing, vol. 15, no. 2, pp. 58-70.

\section{References:}

1. Krykavs'kyj, Ye.V. Pokhyl'chenko, O.A. and Fertch, M. (2017), Lohistyka ta upravlinnia lantsiuhom postavok [Logistics and supply chain management], Vydavnytstvo L'vivs'koi politekhniky, L'viv, Ukraine.

2. Aliu, M.M. and Oni, E.O. (2020), "A review on marketing strategies and sustainable competitive advantage of smes in the manufacturing sector", Covenant Journal of Entrepreneurship, vol. 4, no. 2, pp. 111-117.

3. Breuker, D. Matzner, M. Delfmann, P. and Becker, J. (2016), "Comprehensible Predictive Models for Business Processes", MIS Quarterly, vol. 40, no. 4, pp. 1009-1034.

4. Brunk, J. Stierle, M. Papke, L. Revoredo, K. Matzner, M. and Becker, J. (2021), "Cause vs. effect in contextsensitive prediction of business process instances", Information Systems, vol. 95, p. 101635.

5. Chang, S. Zhang, Z. Wang, X. and Dong, Y. (2020), "Optimal acquisition and retention strategies in a duopoly model of competition", European Journal of Operational Research, vol. 282, no. 2, pp. 677-695.

6. Hosseini, A.S. Soltani, S. and Mehdizadeh, M. (2018), "Competitive advantage and its impact on new product development strategy (Case study: Toos Nirro technical firm)", Journal of Open Innovation: Technology, Market, and Complexity, vol. 4, no. 2, pp. 17-22.

7. Kleindorfer, P.R. Singhal, K. and Van Wassenhove, L.N. (2009), "Sustainable operations management", Production and operations management, vol. 14, no. 4, pp. $482-492$.

8. Mehdiyev, N. Evermann, J., and Fettke, P. (2020), "A novel business process prediction model using a deep learning method", Business \& information systems engineering, vol. 62, no. 2, pp. 143-157.

9. Rakic, M. Rakic, B. and Stanojevic, L. (2018), "Consumer Ethnocentrism-Marketing Challenge for Companies: The Case of Serbia", Management: Journal of Sustainable Business and Management Solutions in Emerging Economies, vol. 23, no. 3, pp. 81-92.

10. Ramos, T.R.P. de Morais, C.S. and Barbosa-Povoa, A.P. (2018), "The smart waste collection routing problem: Alternative operational management approaches", Expert Systems with Applications, vol. 103, pp. 146-158.

11. Shokuhi, A. and Nabavi Chashmi, S.A. (2019), "Formulation of Bank Melli Iran Marketing Strategy Based on Porter 'S Competitive Strategy", Journal of Business-toBusiness Marketing, vol. 26, no. 2, pp. 209-215.

12. Soto-Silva, W.E. Nadal-Roig, E. Gonzalez-Araya, M.C. and Pla-Aragones, L.M. (2016), "Operational research models applied to the fresh fruit supply chain", European Journal of Operational Research, vol. 251, no. 2, pp. 345-355.

13. Velychko, O. and Velychko, L. (2017), "Logistical modelling of managerial decisions in social and marketing business systems", Journal of International Studies, vol. 10, no. 3 , pp. $206-219$.

14. Velychko, O. Velychko, L. Butko, M. and Khalatur, S. (2019), "Modelling of strategic managerial decisions in the system of marketing logistics of enterprise", Innovative Marketing, vol. 15, no. 2, pp. 58-70.

Стаття надійшла до редакиї 03.03.2021 p. 